\title{
Establishment of Sufficiency Ranges to Determine the Nutritional Status of 'Gigante' Forage Cactus Pear-Micronutrients
}

\author{
Jean F. T. Alves ${ }^{1}$, Sérgio L. R. Donato ${ }^{2}$, Paulo E. R. Donato ${ }^{2}$, João Abel da Silva ${ }^{2} \&$ Bruno V. C. Guimarães $^{3}$ \\ ${ }^{1}$ Instituto Mineiro de Agropecuária, Espinosa, Minas Gerais, Brazil \\ ${ }^{2}$ Instituto Federal Baiano, Setor de Agricultura, Guanambi, Bahia, Brazil \\ ${ }^{3}$ Instituto Federal do Amazonas, Departamento de Ciências Agrárias, São Gabriel da Cachoeira, Amazonas, \\ Brazil \\ Correspondence: Bruno V. C. Guimarães, Instituto Federal do Amazonas, Departamento de Ciências Agrárias, \\ São Gabriel da Cachoeira, BR 307, km 03, Amazonas, CEP: 69750000, Brazil. Tel: 55-77-99121-4608. E-mail: \\ bvinicius20@yahoo.com.br
}

Received: August 19, 2019

doi:10.5539/jas.v11n18p222
Accepted: October 3, $2019 \quad$ Online Published: November 15, 2019

URL: https://doi.org/10.5539/jas.v11n18p222

\begin{abstract}
Micronutrient sufficiency ranges are of great importance in crop nutritional diagnosing for improved fertilizer recommendations under field conditions. The objective of this paper was establishing the micronutrients ranges in the cladodes for the evaluation of the nutritional status of 'Gigante' forage cactus pear. Micronutrients contents in cladodes and dry matter yield of 72 plots were used. The experiment was composed of four cattle manure rates $(0$, 30,60 , and $90 \mathrm{Mg} \mathrm{ha}^{-1}$ year $\left.^{-1}\right)$, three spacings $(1.00 \times 0.50,2.00 \times 0.25$, and $3.00 \times 1.00 \times 0.25 \mathrm{~m}$ ), and two production cycles, in a $4 \times 3 \times 2$ factorial plan, designed in randomized blocks, with three replicates. Sufficiency ranges of plots with dry matter $\geq 19.93 \mathrm{Mg} \mathrm{ha}^{-1} \mathrm{cycle}^{-1}$ were determined as well as the mathematical chance for plots with dry matter $\geq 23.75 \mathrm{Mg} \mathrm{ha}^{-1}$ cycle $^{-1}$ and the critical level. The sufficiency range, critical level and mathematical chance are, respectively, for each micronutrient, in $\mathrm{mg} \mathrm{kg}^{-1}: \mathrm{B}, 22.3-32.7 ; 23.7 ; 20.36-27.94 ; \mathrm{Cu}$, 2.0-3.7; 1.6; 1.8-2.8; Fe, 61.1-126.6; 62.0; 35.8-85.3; Mn, 260.0-507.7; 111.0; 54.8-252.2; Zn, 34.5-57.8; 30.3; 19.7-48.5; and, Na, 29.8-56.2; 19.4; 26.6-42.7. For B, Zn, and Na, the sufficiency range, mathematical chance, and the critical level are adequate; for $\mathrm{Cu}, \mathrm{Fe}$, and $\mathrm{Mn}$, the critical level and mathematical chance are more adequate for nutritional evaluation of 'Gigante' forage cactus pear, associated with dry matter yield ranging from 21.8 to 31.2 $\mathrm{Mg} \mathrm{ha}^{-1} \mathrm{cycle}^{-1}$.
\end{abstract}

Keywords: Opuntiaficus, fertilization, nutritional evaluation

\section{Introduction}

The forage cactus pear (Opuntia ficus-indica Mill) has special morphologic mechanisms that allow it to adapt to drought conditions, which makes its cultivation essential in the Brazilian semiarid (Guimarães et al., 2019). For this reason, when adopting efficient managements in seasons with high water and nutrients availability, mainly concerning fertilization rates, the cactus modifies its physiological behavior, which leads to an increase in growth, yield, and nutritional quality.

Recent studies has considered chemical fertilizers (Silva et al., 2012), organic fertilizers (Donato et al., 2014a), and organo-mineral fertilizers (Padilha Júnior et al., 2016) as alternatives for increasing yields in forage cactus pear. The results show the influence on nutrient uptake (Donato et al., 2017; Silva et al., 2016a), on vegetative growth (Silva et al., 2016b), on nutritional status of the plant (Galizzi et al., 2004), on nutritional value of the forage, and on dry matter yield (Silva et al., 2013).

The chemical analysis of plant tissues is important to evaluate the nutritional status of crops as a complement of the soil chemical analysis and the visual diagnosis; as a result, it reflects the nutrient dynamics within the soil/plant system. Nevertheless, it requires the definition of standards and critical levels of nutrients so as to correctly interpret the results. To do so, there are several methods: sufficiency range (Martinez et al., 2003), mathematical chance (MCh), Diagnosis and Recommendation Integrated System (DRIS), Compositional Nutrient Diagnosis (CND), and critical level through the standard normal distribution (NCRIz) (Maia et al., 2001). 
Sufficiency ranges and critical levels were established for forage cactus pear grown in Mexico (Blanco-Macías et al., 2010); though, there is demand for a standard for interpreting the micronutrients contents in tissues of cladodes, which sometimes limits the crop yield. Therefore, the aim of this study wasestablishing sufficiency ranges of micronutrients in tissues of cladodes for 'Gigante' forage cactus pear.

\section{Material and Methods}

A field trial was conducted from 2009 and 2012 on an experimental area of Instituto Federal Baiano, campus

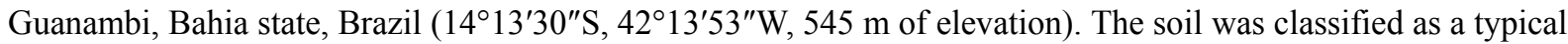
dystrophic red-yellow Latosol (Oxysol). Climatic conditions were hypoxerophytic Caatinga; mean annual rainfall and temperature were $680 \mathrm{~mm}$ and $26^{\circ} \mathrm{C}$, respectively.

In this study, micronutrient contents - boron (B), copper $(\mathrm{Cu})$, Iron $(\mathrm{Fe})$, manganese $(\mathrm{Mn})$, zinc $(\mathrm{Zn})$, and sodium (Na) - as well as dry matter yield (DMY) and green matter yield (GMY) were evaluated using 'Gigante' forage cactus pear cladode samples; data from Donato et al. (2014a, 2014b, 2016) and Barros et al. (2016) for the first and second cycle were used, respectively.

Cladode micronutrient contents were measured considering a experimental design with four cattle manure rates $\left(0,30,60\right.$, and $\left.90 \mathrm{Mg} \mathrm{ha}^{-1} \mathrm{year}^{-1}\right)$, three spacings $(1.0 \times 5.00,2.00 \times 0.24$; and $1.00 \times 0.25 \mathrm{~m})$, and two production cycles (600 and 930 days after planting). These treatments were arranged in a $4 \times 3 \times 2$ factorial laid out on a randomized block design with three replicates, totaling 72 experimental plots.

Sufficiency range (SR) and critical range (CR) were standardized by taking into account the mean \pm standard deviation of micronutrient contents measured in experimental plots yielding dry matter equal to or higher than the average yield (Martinez et al., 2003). Using the mathematical change procedure (MCh), data from plots with $\mathrm{DMY} \geq 23.75 \mathrm{Mg} \mathrm{ha}^{-1}$ cycle ${ }^{-1}$ were selected (Camacho et al., 2012).

Therefore, sufficiency ranges were determined by the equation: $S R=\bar{x} \pm k S \bar{x} ; S R \geq(\bar{x}-k S \bar{x})<(\bar{x}+k S \bar{x})$, where, $\bar{x}$ is the mean tissue content of each micronutrient, $S \bar{x}$ is the standard deviation, $\sqrt{S}$ is the square root of the variance, and $\mathrm{k}$ is the correction factor for adjusting the sufficiency ranges. The $\mathrm{k}$ values were established based on the coefficient of variation (CV) of each nutrient: $\mathrm{k}=1.0$ for nutrients with CV below $20 \%$; $\mathrm{k}=0.8$ for CV between 20.01 and $40 \%$; $\mathrm{k}=0.6$ for $\mathrm{CV}$ between 40.01 and $80 \%$; and $\mathrm{k}=0.4$ for $\mathrm{CV}$ higher than $80 \%$ (Martinez et al., 2003).

In addition to SR, cladode micronutrient contents were separated into four levels: deficient (DEF), marginal (MAR), high (HI), and very high (VHI). These classes were established according to the following procedure: $\mathrm{DEF}<(\overline{\mathrm{x}}-2 \mathrm{kS} \overline{\mathrm{x}}) ; \quad \mathrm{MARG} \geq(\overline{\mathrm{x}}-2 \mathrm{kS} \overline{\mathrm{x}})$ and $<(\overline{\mathrm{x}}-\mathrm{kS} \overline{\mathrm{x}}) \quad ; \quad \mathrm{IGH} \geq(\mathrm{x}+\mathrm{kS} \overline{\mathrm{x}})$ and $<(\overline{\mathrm{x}}+2 \mathrm{kSx}) \quad$; $\mathrm{VHIGH} \geq(\overline{\mathrm{x}}+2 \mathrm{kS} \overline{\mathrm{x}})$.

Cladode micronutrient contents were classified based on confidence intervals (CI) determined by the model: $\mathrm{CI}=\overline{\mathrm{x}} \pm \mathrm{t} \alpha \cdot \mathrm{S} \overline{\mathrm{x}}$, where $\overline{\mathrm{x}}$ is the mean, $\mathrm{S} \overline{\mathrm{x}}$ is the standard deviation of the mean, and t $\alpha$ is the bilateral $\mathrm{t}$ value at $10 \%$ of probability level for high yielding plots.

By the standard normal distribution, critical levels were determined for cladode micronutrient contents using the model proposed by Maia et al. (2001): $\mathrm{CL}_{\mathrm{I}}=\left(1,281552 \cdot \mathrm{S}_{1}+\overline{\mathrm{x}}_{1}\right) /\left(1,281552 \cdot \mathrm{Sx}_{2}+\overline{\mathrm{x}}_{2}\right)$; where, CL is the critical level; $S \bar{x}_{1}$ and $\mathrm{a}_{1}$ are the standard deviation and average yield $(\mathrm{Y})$; and $S \overline{\mathrm{x}}_{2} \cdot \mathrm{ex}_{2}$ are standard deviation and average of $Q$, which is defined as the ratio between $Y$ and $n_{i}, Q=Y / n_{i}$; where $n_{i}$ is the nutrient content used to determine the critical level.

Using the mathematical chance model (MCh), micronutrient contents were split into classes by the square root of the number of terms whose intervals were calculated by the division between nutrient content and the number of pre-defined classes.

Mathematical chance (MChi) was determined by the following model: $\mathrm{MCh}_{\mathrm{i}}=\left[\mathrm{MCh}\left(\mathrm{A}_{\mathrm{i}} / \mathrm{A}\right) \times \mathrm{MCh}\left(\mathrm{A}_{\mathrm{i}} / \mathrm{C}_{\mathrm{i}}\right)\right]^{0.5}$, where, $\operatorname{MCh}\left(\mathrm{A}_{\mathrm{i}} / \mathrm{A}\right)=\mathrm{Y}\left(\mathrm{A}_{\mathrm{i}} / \mathrm{A}\right) \times \mathrm{YIELD} \mathrm{II}_{\mathrm{i}} ; \mathrm{Y}\left(\mathrm{A}_{\mathrm{i}} / \mathrm{A}\right)=$ frequency of high-yielding plots; $\mathrm{YIELD}_{\mathrm{i}}$, average yield in the class $i\left(\mathrm{Mg} \mathrm{ha}^{-1}\right.$ year $\left.^{-1}\right) ; \mathrm{MCh}\left(\mathrm{A}_{\mathrm{i}} / \mathrm{C}_{\mathrm{i}}\right)=\mathrm{Y}\left(\mathrm{A}_{\mathrm{i}} / \mathrm{C}_{\mathrm{i}}\right) \times \mathrm{YIELD}_{\mathrm{i}}$; and $\mathrm{Y}\left(\mathrm{A}_{\mathrm{i}} / \mathrm{C}_{\mathrm{i}}\right)=$ frequency of high-yielding plots of class $i$ in relation to the overall total of high-yielding plots in the class $i$.

Lower (LLi) and upper (ULi) limits were established for each micronutrient, which corresponded to the normal range due to its higher reference value: $\mathrm{MCh}$; furthermore, the highest total frequency of plots in class $i$ and the highest frequency of plots with dry matter yield equal to or higher than $23.75 \mathrm{Mg} \mathrm{ha}^{-1}$ cycle $^{-1}$ in class I were considered.

Moreover, the correlation between the micronutrients contents in the tissues and DMY with micronutrients uptake and green mass yield was estimated. 


\section{Results and Discussion}

The dry matter content linearly decreases alongside the green mass yield, GMY, while the dry matter yield, DMY increases (Figure 1A). The correlations of the micronutrients contents in cladodes and DMY of 'Gigante' cactus pear with the extraction of the respective micronutrients from the soil are positive and significant (Figure 1), except for DMY and uptake of Mn, non-significant. The highest values were recorded for DMY with B uptake (0.86), and for Fe content in cladodes with Fe uptake (0.85). Positive correlations between nutrients contents in cladodes and in the soil were established, in which $\mathrm{Mn}$ with $\mathrm{Ca}$ exhibited a negative correlation $(-0.29)$ while Zn with P, positive (0.26) (Galizzi et al., 2004).

A.

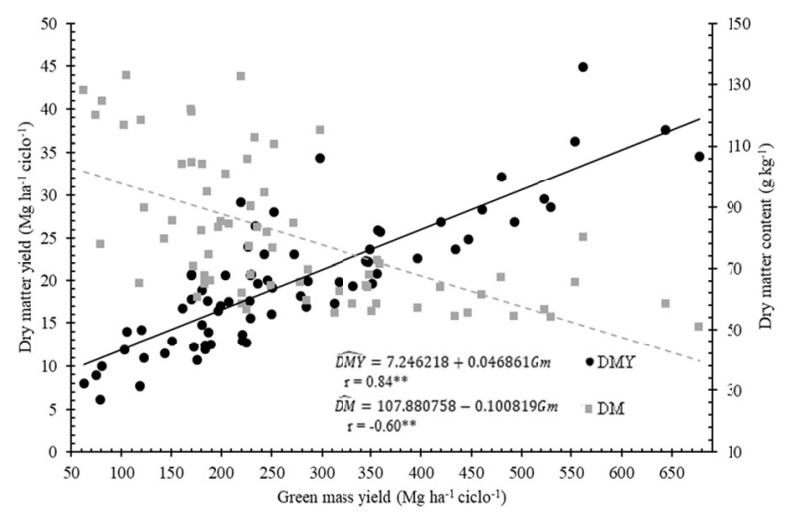

C.

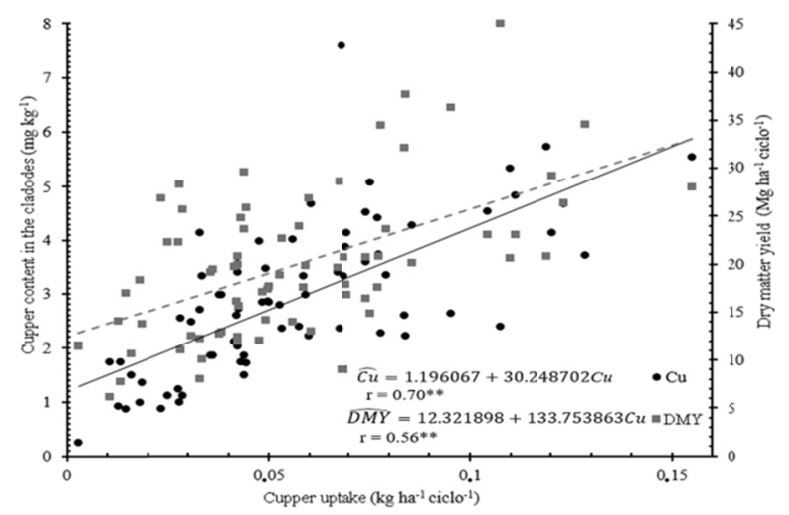

E.

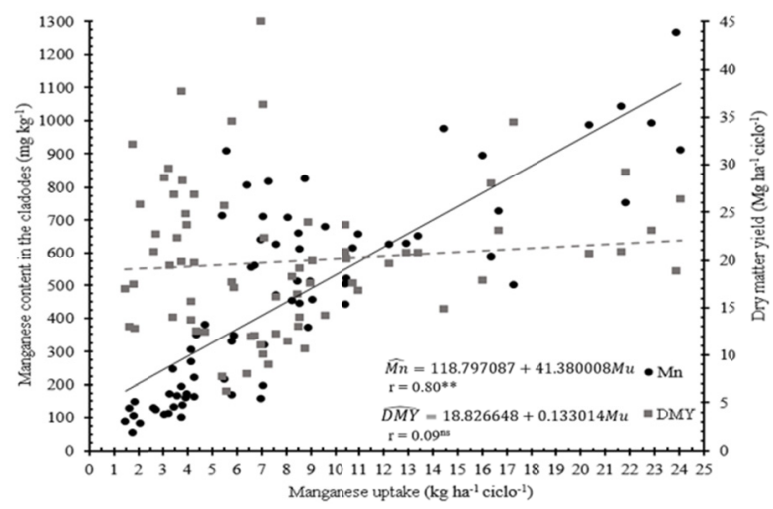

B.

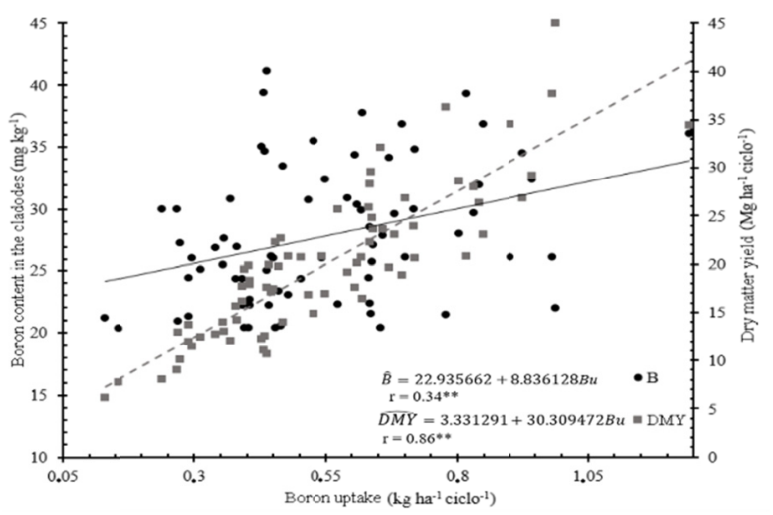

D.

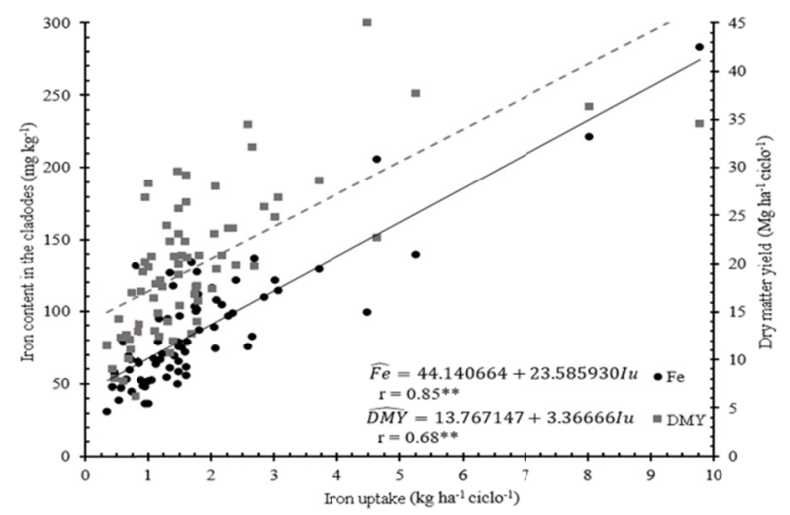

F.

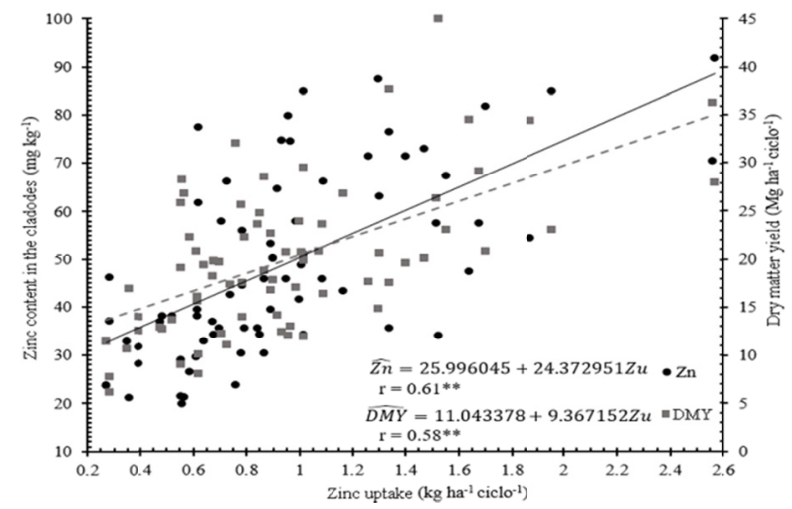




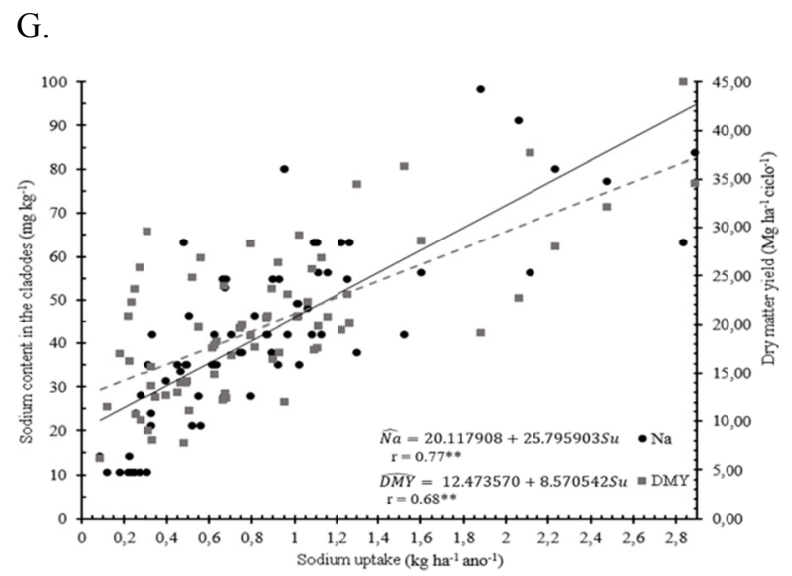

Figure 1. Correlations of yield and dry matter content with green mass yield (A); micronutrients contents in tissues of cladodes and dry matter yield with extraction/exportation of respective micronutrients by 'Gigante' forage cactus pear, fertilized with different cattle manure rates, in two production cycles. B: boron, C: cupper, D: iron, E: manganese, F: zinc and, G: sodium. Significance level of the coefficients: ${ }^{* *} 0.01$ and ${ }^{\text {ns }}$ Not significant

Source: Basic data, Donato et al. (2014a, 2014b, 2016); Barros et al. (2016).

The positive and significant correlations of micronutrients contents in the cladodes and dry matter yield (DMY) with the extraction of respective nutrients (Figure 1) allow to establish sufficiency ranges (SR), as well as to set five classes for the evaluation of the nutritional status of 'Gigante' forage cactus pear (Table 1). Donato et al. (2017) added that crop yield highly responds to the availability of nutrients in the soil for the plant to take up; thus, sufficiency range correlates with dry matter yield.

Table 1. Values of micronutrients contents in tissues of cladodes associated with the dry matter yield (DMY) for evaluating the nutritional status of 'Gigante' forage cactus pear by the sufficiency range technique

\begin{tabular}{|c|c|c|c|c|c|c|c|}
\hline Contents & DMY & B & $\mathrm{Cu}$ & $\mathrm{Fe}$ & $\mathrm{Mn}$ & $\mathrm{Zn}$ & $\mathrm{Na}$ \\
\hline Classes & $\mathrm{Mg} \mathrm{ha}^{-1}$ cycle $^{-1}$ & -------- & & ---------- n & $\mathrm{kg}^{-1}-$ & & \\
\hline Deficient & $<17.0$ & $<17.1$ & $<1.1$ & $<28.4$ & $<136.0$ & $<15.0$ & $<16.6$ \\
\hline Marginal & $17.0-21.8$ & $17.1-22.3$ & $1.1-2.0$ & $28.4-61.1$ & $136.0-260.0$ & $15.0-30.6$ & $16.6-29.8$ \\
\hline Sufficient & $21.8-31.2$ & $22.3-32.7$ & $2.0-3.7$ & $61.1-126.6$ & $260.0-507.7$ & $34.5-57.8$ & $29.8-56.2$ \\
\hline Good (high) & $31.2-36.0$ & $32.7-37.8$ & $3.7-4.5$ & $126.6-159.3$ & $507.7-631.6$ & $57.8-69.5$ & $56.2-69.3$ \\
\hline Very good (very high) & $\geq 36.0$ & $\geq 37.8$ & $\geq 4.5$ & $\geq 159.3$ & $\geq 631.6$ & $\geq 69.5$ & $\geq 69.3$ \\
\hline Mean & 19.93 & 27.77 & 2.92 & 87.30 & 461.49 & 49.11 & 42.56 \\
\hline Standard Deviation ${ }^{1}$ & 7.64 & 5.52 & 1.38 & 42.73 & 294.21 & 18.93 & 20.40 \\
\hline $\mathrm{CV}^{1}(\%)$ & 38.34 & 19.89 & 47.17 & 48.94 & 63.75 & 38.54 & 47.93 \\
\hline $\mathrm{CI}^{2}$ & $16.5-36.5$ & $18.7-36.3$ & $0.5-5.3$ & $1.4-186.3$ & $0-909.0$ & $13.2-79.2$ & $5.8-80.2$ \\
\hline
\end{tabular}

Note. ${ }^{1}$ Mean, standard deviation and coefficient of variation (CV) refer to $72 \mathrm{plots} ;{ }^{2}$ Confidence interval of crude protein and micronutrients contents in tissues of cladodes of 'Gigante' forage cactus pear fertilized with different cattle manure rates, in two production cycles.

The highest values of MCh are for B contents in cladodes of 'Gigante' cactus pear associated with DMY higher than or equal to $23.75 \mathrm{Mg} \mathrm{ha}^{-1}$ cycle $^{-1}$ were observed in the classes 4 and 5 (20.3-27.9 $\mathrm{mg} \mathrm{kg}^{-1}$ ) (Table 2). These values are within the SR (22.3-32.7 mg kg-1), and as for the NCRIz $\left(23.7 \mathrm{mg} \mathrm{kg}^{-1}\right)$, it coincides with the middle point of the MCh interval (Table 3). B contents within the MCh and in the lower limit of the SR $\left(22.6 \mathrm{~g} \mathrm{~kg} \mathrm{k}^{-1}\right)$ were obtained by Silva et al. (2012) with 200-150-100 kg ha-1 year ${ }^{-1}$ of $\mathrm{N}-\mathrm{P}_{2} \mathrm{O}_{5}-\mathrm{K}_{2} \mathrm{O}$. 
Table 2. Values of mathematical chance (MCh) established for different distribution classes of micronutrients in tissues of cladodes of 'Gigante' forage cactus pear, fertilized with different cattle manure rates, in two production cycles

\begin{tabular}{|c|c|c|c|c|c|c|c|c|c|c|}
\hline Classes & $\begin{array}{l}\mathrm{LLi}^{2} \\
\left(\mathrm{mg} \mathrm{kg}^{-1}\right)\end{array}$ & $\begin{array}{l}\mathrm{UPi}^{3} \\
\left(\mathrm{mg} \mathrm{kg}^{-1}\right)\end{array}$ & $\begin{array}{l}\text { YIELDi }^{4} \\
\left(\mathrm{Mg} \mathrm{ha}^{-1} \text { cycle }^{-1}\right)\end{array}$ & Plot class $i^{5}$ & $\begin{array}{l}\text { High-yielding } \\
\text { plot class } i^{6}\end{array}$ & $\mathrm{P} 1^{7}$ & $\mathrm{P} 2^{8}$ & $\operatorname{MCh}\left(\mathrm{A}_{\mathrm{i}} / \mathrm{A}\right)^{9}$ & Classes & $\begin{array}{l}\mathrm{LLi}^{2} \\
\left(\mathrm{mg} \mathrm{kg}^{-1}\right)\end{array}$ \\
\hline \multicolumn{11}{|l|}{ Boron } \\
\hline 1 & 35.54 & 39.32 & 26.06 & 3 & 1 & 0.06 & 0.33 & 1.45 & 1 & 35.54 \\
\hline 2 & 31.74 & 35.53 & 25.75 & 4 & 3 & 0.17 & 0.75 & 4.29 & 2 & 31.74 \\
\hline 3 & 27.95 & 31.73 & 23.79 & 7 & 3 & 0.17 & 0.43 & 3.97 & 3 & 27.95 \\
\hline 4 & 24.15 & 27.94 & 26.50 & 9 & 5 & 0.28 & 0.56 & 7.36 & 4 & 24.15 \\
\hline 5 & 20.36 & 24.14 & 29.18 & 9 & 6 & 0.33 & 0.67 & 9.73 & 5 & 20.36 \\
\hline \multicolumn{11}{|l|}{ Cupper } \\
\hline 1 & 4.76 & 5.73 & 23.10 & 4 & 1 & 0.06 & 0.25 & 1.28 & 1 & 4.76 \\
\hline 2 & 3.78 & 4.75 & 24.67 & 4 & 2 & 0.11 & 0.50 & 2.74 & 2 & 3.78 \\
\hline 3 & 2.79 & 3.77 & 24.06 & 5 & 1 & 0.06 & 0.20 & 1.34 & 3 & 2.79 \\
\hline 4 & 1.81 & 2.78 & 30.18 & 11 & 8 & 0.44 & 0.73 & 13.41 & 4 & 1.81 \\
\hline 5 & 0.83 & 1.80 & 25.71 & 8 & 2 & 0.11 & 0.25 & 2.86 & 5 & 0.83 \\
\hline \multicolumn{11}{|l|}{ Iron } \\
\hline 1 & 233.69 & 283.13 & 34.54 & 1 & 1 & 0.06 & 1.00 & 1.92 & 1 & 233.69 \\
\hline 2 & 184.23 & 233.68 & 29.44 & 2 & 1 & 0.06 & 0.50 & 1.64 & 2 & 184.23 \\
\hline 3 & 134.78 & 184.22 & 37.67 & 1 & 1 & 0.06 & 1.00 & 2.09 & 3 & 134.78 \\
\hline 4 & 85.32 & 134.77 & 26.30 & 10 & 5 & 0.28 & 0.50 & 7.31 & 4 & 85.32 \\
\hline 5 & 35.87 & 85.31 & 25.27 & 18 & 10 & 0.56 & 0.56 & 14.04 & 5 & 35.87 \\
\hline \multicolumn{11}{|c|}{ Manganese } \\
\hline 1 & 844.39 & 1041.77 & 22.70 & 4 & 1 & 0.06 & 0.25 & 1.26 & 1 & 844.39 \\
\hline 2 & 647.01 & 844.38 & 24.28 & 3 & 1 & 0.06 & 0.33 & 1.35 & 2 & 647.01 \\
\hline 3 & 449.62 & 647.00 & 24.78 & 5 & 2 & 0.11 & 0.40 & 2.75 & 3 & 449.62 \\
\hline 4 & 252.24 & 449.61 & 23.30 & 3 & 1 & 0.06 & 0.33 & 1.29 & 4 & 252.24 \\
\hline 5 & 54.85 & 252.23 & 28.91 & 17 & 13 & 0.72 & 0.76 & 20.88 & 5 & 54.85 \\
\hline \multicolumn{11}{|l|}{ Zinc } \\
\hline 1 & 77.39 & 91.80 & 23.92 & 3 & 1 & 0.06 & 0.33 & 1.33 & 1 & 77.39 \\
\hline 2 & 62.97 & 77.38 & 25.01 & 4 & 1 & 0.06 & 0.25 & 1.39 & 2 & 62.97 \\
\hline 3 & 48.56 & 62.96 & 26.28 & 5 & 3 & 0.17 & 0.60 & 4.38 & 3 & 48.56 \\
\hline 4 & 34.14 & 48.55 & 26.38 & 11 & 6 & 0.33 & 0.55 & 8.79 & 4 & 34.14 \\
\hline 5 & 19.72 & 34.13 & 28.39 & 9 & 7 & 0.39 & 0.78 & 11.04 & 5 & 19.72 \\
\hline \multicolumn{11}{|l|}{ Sodium } \\
\hline 1 & 75.04 & 91.17 & 29.31 & 4 & 3 & 0.17 & 0.75 & 4.89 & 1 & 75.04 \\
\hline 2 & 58.90 & 75.03 & 32.53 & 2 & 1 & 0.06 & 0.50 & 1.81 & 2 & 58.90 \\
\hline 3 & 42.76 & 58.89 & 24.81 & 7 & 2 & 0.11 & 0.29 & 2.76 & 3 & 42.76 \\
\hline 4 & 26.62 & 42.75 & 26.60 & 12 & 8 & 0.44 & 0.67 & 11.82 & 4 & 26.62 \\
\hline 5 & 10.48 & 26.61 & 24.83 & 7 & 4 & 0.22 & 0.57 & 5.52 & 5 & 10.48 \\
\hline \multicolumn{11}{|l|}{ Boron } \\
\hline 1 & 35.54 & 39.32 & 26.06 & 3 & 1 & 0.06 & 0.33 & 1.45 & 1 & 35.54 \\
\hline 2 & 31.74 & 35.53 & 25.75 & 4 & 3 & 0.17 & 0.75 & 4.29 & 2 & 31.74 \\
\hline 3 & 27.95 & 31.73 & 23.79 & 7 & 3 & 0.17 & 0.43 & 3.97 & 3 & 27.95 \\
\hline 4 & 24.15 & 27.94 & 26.50 & 9 & 5 & 0.28 & 0.56 & 7.36 & 4 & 24.15 \\
\hline
\end{tabular}

Note. ${ }^{1}$ Camacho et al. (2012); ${ }^{2}$ Lower limit of class $i ;{ }^{3}$ Upper limit of class $i$; ${ }^{4}$ Average dry matter yield (DMY, $\mathrm{Mg} \mathrm{ha}^{-1}$ year $^{-1}$ ) of plots in the class $i ;{ }^{5}$ Total number of plots in the class $i ;{ }^{6}$ Total number of high-yielding plots in the class $i$, DMY $\geq 23.75 \mathrm{Mg} \mathrm{ha}^{-1}$, which corresponds to the average DMY +0.5 standard deviation; ${ }^{7}$ Frequency of high-yielding plots in the class $i$ in relation to the total number of high-yielding plots; ${ }^{8}$ Frequency of high-yielding plots in the class $i$ in relation to the total number of plots in the class $i ;{ }^{9} \mathrm{MCh}\left(\mathrm{A}_{\mathrm{i}} / \mathrm{A}\right)=\mathrm{Y}\left(\mathrm{A}_{\mathrm{i}} / \mathrm{A}\right) \times$ $\operatorname{YIELD}_{\mathrm{i}} ;{ }^{10} \mathrm{MCh}\left(\mathrm{A}_{\mathrm{i}} / \mathrm{C}_{\mathrm{i}}\right)=\mathrm{Y}\left(\mathrm{A}_{\mathrm{i}} / \mathrm{C}_{\mathrm{i}}\right) \times \mathrm{YIELD}_{\mathrm{i}} ;{ }^{11} \mathrm{MCh}_{\mathrm{i}}=\left[\mathrm{MCh}\left(\mathrm{A}_{\mathrm{i}} / \mathrm{A}\right) \times \mathrm{MCh}\left(\mathrm{A}_{\mathrm{i}} / \mathrm{C}_{\mathrm{i}}\right)\right]^{0.5}$. 
Table 3. Normal ranges of micronutrients in tissues of cladodes of 'Gigante' forage cactus pear obtained by the sufficiency range technique (SR), by the mathematical chance method (MCh), and by the critical level through the standard normal distribution (NCRIz) associated with the dry matter yield (DMY)

\begin{tabular}{|c|c|c|c|c|c|c|c|}
\hline Attributes & $\mathrm{DMY}^{1}$ & B & $\mathrm{Cu}$ & $\mathrm{Fe}$ & $\mathrm{Mn}$ & $\mathrm{Zn}$ & $\mathrm{Na}$ \\
\hline Methods & $\mathrm{Mg} \mathrm{ha}^{-1}$ cycle $^{-1}$ & \multicolumn{6}{|c|}{ - } \\
\hline SR & $21.8-31.2^{1}$ & $22.3-32.7$ & $2.0-3.7$ & $61.1-126.6$ & $260.0-507.7$ & $34.5-57.8$ & $29.8-56.2$ \\
\hline $\mathrm{MCh}^{3}$ & $>23.75$ & $20.3-27.9$ & $1.8-2.8$ & $35.8-85.3$ & $54.8-252.2$ & $19.7-48.5$ & $26.6-42.7$ \\
\hline $\mathrm{NCRIz}^{3}$ & $23.75^{4}$ & 23.7 & 1.6 & 62.0 & 111.0 & 30.3 & 19.4 \\
\hline
\end{tabular}

Note. ${ }^{1}$ Range of dry matter yield associated with the normal ranges of crude protein and micronutrients; ${ }^{2}$ Estimated from the upper and lower limits of the frequency class with higher values of mathematical chance (Camacho et al., 2012), higher frequency of the total number of plots in the class iand higher frequency of high-yielding plots in the class $i ;{ }^{3}$ According to Maia et al. (2001); ${ }^{4}$ Average DMY + 0.5 standard deviation, used to separate high from low yielding plots in the class $i$; ${ }^{5}$ Sufficiency range and critical level (Blanco-Macías et al., 2010).

$\mathrm{B}$ was the penultimate micronutrient in the order of extraction/exportation to the dry matter of the plant, $29.8 \mathrm{~g}$ $\mathrm{Mg}^{-1}$ (Donato, 2011) and $22.8 \mathrm{~g} \mathrm{Mg}^{-1}$ (Silva et al., 2016a). This is consistent with the lesser degree of association between the $\mathrm{B}$ content in the cladode and its extraction from the soil (0.36), even though there is a higher degree in DMY with B extraction (Figure 1B), and B is the main micronutrient related to the growth of the cactus pear (Dubeux Júnior \& Santos, 2005). SR, MCh, and NCRIz are suitable for evaluating the nutritional status of cactus pear.

The highest value of $\mathrm{MCh}$ for the $\mathrm{Cu}$ contents in cladodes of 'Gigante' forage cactus pear was found in the class 4 (1.8-2.8 $\mathrm{mg} \mathrm{kg}^{-1}$ ) (Table 2). The lower limit (LLi) of MCh is similar to that of NCRIz (1.6 mg kg$\left.~^{-1}\right)$, while the upper limit (ULi) is within the SR (2.0-3.7 $\mathrm{mg} \mathrm{kg}^{-1}$ ) (Table 3). Cu contents above the SR $\left(5.1 \mathrm{mg} \mathrm{kg}^{-1}\right) \mathrm{were}^{-1}$ obtained by Silva et al. (2012) for forage production, with 200-150-100 kg ha ${ }^{-1}$ year ${ }^{-1}$ of $\mathrm{N}_{-} \mathrm{P}_{2} \mathrm{O}_{5}-\mathrm{K}_{2} \mathrm{O}$; whereas Galizzi et al. (2004) found $\mathrm{Cu}$ contents within the SR $\left(2.9 \mathrm{mg} \mathrm{kg}^{-1}\right)$ for fruit production, with $100-50-100-50 \mathrm{~kg}$ $\mathrm{ha}^{-1}$ of N-P-K-Mg. $\mathrm{Cu}$ is the micronutrient with lower extraction/exportation to the dry matter of forage cactus pear, $3.1 \mathrm{~g} \mathrm{Mg}^{-1}$ (Donato, 2011) and $5.3 \mathrm{~g} \mathrm{Mg}^{-1}$ (Silva et al., 2016a); thus, the NCRIz and MCh are more suitable for evaluating the nutritional status for $\mathrm{Cu}$.

The highest value of MCh for Fe contents in cladodes of the plant was observed in the class 5 (35.87-85.31 mg $\mathrm{kg}^{-1}$ ) (Table 2). The NCRIz $\left(62.0 \mathrm{mg} \mathrm{kg}^{-1}\right)$ is an intermediate value within the MCh and is found in the lower limit of the SR. As for the ULi of MCh, it is in the SR (61.1-126.6 mg kg${ }^{-1}$ ) (Table 3). Fe contents below the SR, within, however, the MCh, were reported by Silva et al. (2012), $48.5 \mathrm{mg} \mathrm{kg}^{-1}$ and by Galizzi et al. (2004), $41 \mathrm{mg}$ $\mathrm{kg}^{-1}$. Fe was the second micronutrient in order of extraction/exportation to the dry matter of the plant, $72.5 \mathrm{~g}$ $\mathrm{Mg}^{-1}$ (Donato, 2011) and third, $49.3 \mathrm{~g} \mathrm{Mg}^{-1}$ (Silva et al., 2016a). Therefore, the NCRIz and the MCh are more suitable for evaluating the nutritional status for $\mathrm{Fe}$.

As for Mn, the highest MCh is in the class 5 (54.8-252.2 mg kg-1) (Table 2). The NCRIz (111.0 mg kg-1) is an intermediate value within the MCh and its ULi is found close to the lower limit of the SR $\left(260.0-507.7 \mathrm{mg} \mathrm{kg}^{-1}\right)$ (Table 3). Mn contents are well above the MCh and the SR (Silva et al., 2012), 2,006.0 $\mathrm{mg} \mathrm{kg}^{-1}$, with 200-150-100 kg ha ${ }^{-1}$ year $^{-1}$ of N- $\mathrm{P}_{2} \mathrm{O}_{5}-\mathrm{K}_{2} \mathrm{O}$, within the MCh and below the SR (Galizzi et al., 2004), $138 \mathrm{mg} \mathrm{kg}^{-1}$ with 100-50-100-50 kg ha ${ }^{-1}$ of N-P-K-Mg. Mn is the highest extracted/exported micronutrient to the dry matter by the cactus pear, 638.1 $\mathrm{g} \mathrm{Mg}^{-1}$ (Donato, 2011) and 1,968.23 $\mathrm{g} \mathrm{Mg}^{-1}$ (Silva et al., 2016a); though, the relation between DMY and Mn uptake is not significant (Figure 1E). For this reason, the NCRIz and the MCh are more suitable for evaluating the nutritional status for $\mathrm{Mn}$.

The elevated value of $\mathrm{Mn}$ in tissues of 'Gigante' cactus pear (Silva et al., 2012) and the triple extraction/exportation of Mn (Silva et al., 2016a) is a consequence of the ammonium sulfate as source of $\mathrm{N}$, which reduces the $\mathrm{pH}$, increasing the solubility and absorption of $\mathrm{Mn}^{+2}$. An evidence of this was the reduction in $\mathrm{pH}$ from 5.33 before planting to 4.29 at harvest time due to NPK application. Conversely, lower values are found when manure is applied as it decreases the acidity and increases the adsorption of Mn. Donato et al. (2016) justified the lower contents in the cladodes by the decrease in $\mathrm{pH}$ from 5.4 before planting to 6.0, 6.1, and 6.2 in areas that had 30,60 , and $90 \mathrm{Mg} \mathrm{ha}^{-1}$ year $^{-1}$ of manure applied, respectively.

The highest values of MCh for $\mathrm{Zn}$ contents in cladodes associated with DMY that is higher than or equal to 23.75 $\mathrm{Mg} \mathrm{ha}^{-1}$ cycle $^{-1}$ are in the classes 4 and 5 (19.7-48.5 $\mathrm{mg} \mathrm{kg}^{-1}$ ) (Table 2). The NCRIz (30.3 mg kg-1) is an intermediate value with the MCh and below the lower limit of the SR (34.5-57.8 $\left.\mathrm{mg} \mathrm{kg}^{-1}\right)$, the LLi and ULi of 
the MCh are below the respective limits of the SR (Table 3). Zn contents above the MCh and the SR were observed by Silva et al. (2012), $67.14 \mathrm{mg} \mathrm{kg}^{-1}$ and Galizzi et al. (2004) reported Zn contents within the MCh and below the SR, $23.8 \mathrm{mg} \mathrm{kg}^{-1}$ in average.

$\mathrm{Zn}$ is the third most extracted/exported micronutrient to the dry matter, $58.3 \mathrm{~g} \mathrm{Mg}^{-1}$ (Donato, 2011), and the second, $65.1 \mathrm{~g} \mathrm{Mg}^{-1}$ (Silva et al., 2016a). Its deficiency interferes with synthesis of auxin and protein, and with growth (Epstein \& Bloom, 2006). Therefore, the SR, MCh, and NCRIz are suitable for evaluating the nutritional status for $\mathrm{Zn}$.

The highest values of MCh for Na is in the class 4 (26.7-42.7 $\mathrm{mg} \mathrm{kg}^{-1}$ ) (Table 2). The LLi and ULi of the MCh are below the limits of the SR (29.8-56.2 mg kg-1) and the NCRIz $\left(19.4 \mathrm{mg} \mathrm{kg}^{-1}\right)$ is below the lower limits of the MCh and of the SR (Table 3). Na contents within the MCh and SR were observed by Silva et al. (2012), $40.0 \mathrm{mg}$ $\mathrm{kg}^{-1}$ and by Galizzi et al. (2004), $38.0 \mathrm{mg} \mathrm{kg}^{-1}$. Therefore, SR, MCh and NCRIz are suitable for evaluating the nutritional status for $\mathrm{Na}$.

Amounts of $\mathrm{Na}$ extracted/exported by the plant were $45.9 \mathrm{~g} \mathrm{Mg}^{-1}$ (Donato, 2011) and $32.3 \mathrm{~g} \mathrm{Mg}^{-1}$ (Silva et al., 2016a). Although $\mathrm{Na}$ is not considered to be essential, Epstein \& Bloom (2006) reported that $\mathrm{Na}$ is a micronutrient for plants with crassulacean acid metabolism (CAM), as it is essential for regeneration of phosphoenolpyruvate, substrate in the first carboxylation and its deficiency induces chlorosis and necrosis, and flower drop.

\section{Conclusions}

As for B, Zn, and Na, the sufficiency range (SR), the mathematical chance (MCh) and the NCRIz are more suitable for the evaluation of the nutritional status of 'Gigante' forage cactus pear associated with dry matter yield between 21.8 and $31.2 \mathrm{Mg} \mathrm{ha}^{-1}$ cycle $^{-1}$.

\section{References}

Barros, J. L. de, Donato, S. L. R., Gomes, V. M., Donato, P. E. R., Silva, J. A. da, \& Padilha Júnior, M. C. (2016). Palma forrageira 'Gigante' cultivada com adubação orgânica. Revista Agrotecnologia, 7(1), 53-65. https://doi.org/10.12971/5051

Blanco-Macías, F., Magallanes-Quintanar, R., Valdez-Cepeda, R. D., Vázquez-Alvarado, R., Olivares-Sáenz, E., Gutiérrez-Ornelas, E., ... Murillo-Amador, B. (2010). Nutritional reference values for Opuntia ficus-indica determined by means of the boundary-line approach. Journal of Plant Nutrition and Soil Science, 173, 927-934. https://doi.org/10.1002/jpln.200900147

Camacho, M. A., Silveira, M. V. S. da, Camargo, R. A., \& Natale, W. (2012). Faixas normais de nutrientes pelos métodos ChM, DRIS e CND e nível crítico pelo método de distribuição normal reduzida para laranjeira-pera. Revista Brasileira de Ciência do Solo, 36, 193-200. https://doi.org/10.1590/S0100-06832 012000100020

Donato, P. E. R. (2011). Avaliação bromatológica, morfológica, nutricional e de rendimento em palma forrageira sob diferentes espaçamentos e doses de esterco bovino (p. 134, Doctoral dissertation, UESB, Brazil).

Donato, P. E. R., Donato, S. L. R., Silva, J. A., Pires, A. J. V., Rosa, R. C. C., \& Aquino, A. A. (2016). Nutrition and yield of 'Gigante' cactus pear cultivated with different spacings and organic fertilizer. Revista Brasileira de Engenharia Agrícola e Ambiental, 20, 1083-1088. https://doi.org/10.1590/1807-1929/ agriambi.v20n12p1083-1088

Donato, P. E. R., Donato, S. L. R., Silva, J. A., Pires, A. J. V., \& Silva Júnior, A. A. (2017). Extraction/exportation of macronutrients by cladodes of 'Gigante' cactus pear under different spacing and organic fertilizer. Revista Brasileira de Engenharia Agrícola e Ambiental, 21, 238-243. https://doi.org/ 10.1590/1807-1929/agriambi.v21n4p238-243

Donato, P. E. R., Pires, A. J. V., Donato, S. L. R., Bonomo, P., Silva, J. A., \& Aquino, A. A. (2014a). Morfometria e rendimento da palma forrageira 'Gigante' sob diferentes espaçamentos e doses de adubação orgânica. Revista Brasileira de Ciências Agrárias, 9, 151-158. https://doi.org/10.5039/agraria.v9i1a3252

Donato, P. E. R., Pires, A. J. V., Donato, S. L. R., Silva, J. A. da, \& Aquino, A. A. (2014b). Valor nutritivo da palma forrageira 'Gigante' cultivada sob diferentes espaçamentos e doses de esterco bovino. Revista Caatinga, 27, 163-172. Retrieved from https://periodicos.ufersa.edu.br/index.php/caatinga/article/ view/2762 
Dubeux Júnior, J. C. B., Araújo Filho, J. T. de, Santos, M. V. F. dos, Lira, M. de A., Santos, D. C. dos, \& Pessoa, R. A. S. (2010). Adubação mineral no crescimento e composição mineral da palma forrageira Clone IPA-20. Revista Brasileira de Ciências Agrárias, 5, 129-135. https://doi.org/10.5039/agraria.v5ila591

Epstein, E., \& Bloom, A. J. (2006). Nutrição mineral de plantas: Princípios e perspectivas (2nd ed., p. 403). Londrina: Editora Planta.

Galizzi, F. A., Felker, P., González, C., \& Gardiner, D. (2004). Correlations between soil and cladode nutrient concentrations and fruit yield and quality in cactus pears, Opuntia ficus-indicain a traditional farm setting in Argentina. Journal of Arid Environments, 59, 115-132. https://doi.org/10.1016/j.jaridenv.2004.01.015

Guimarães, B. V. C., Donato, S. L. R., Aspiazú, I., Azevedo, A. M., \& Carvalho, A. J. de. (2019). Comparison of Methods for Harvest Prediction in 'Gigante' Cactus Pear, Journal of Agricultural Science, 11, 14. https://doi.org/10.5539/jas.v11n14p216

Maia, C. E., Morais, E. R. C. de, \& Oliveira, M. de. (2001). Nível crítico pelo critério da distribuição normal reduzida: Uma nova proposta para interpretação de analise foliar. Revista Brasileira de Engenharia Agrícola e Ambiental, 5, 235-238. https://doi.org/10.1590/S1415-43662001000200010

Martinez, H. T. P., Menezes, J. F. S., Souza, R. B. de, Venegas, V. H. A., \& Guimarães, P. T. G. (2003). Faixas críticas de concentrações de nutrientes e avaliação do estado nutricional de cafeeiros em quatro regiões de Minas Gerais. Pesquisa Agropecuária Brasileira, 38, 703-713. https://doi.org/10.1590/S0100-204X2003 000600006

Padilha Júnior, M. C., Donato, S. L. R., Silva, J. B., Donato, P. E. R., \& Souza, E. S. (2016). Características morfométricas e rendimento da palma forrageira 'Gigante' sob diferentes adubações e configurações de plantio. Revista Verde de Agroecologia e Desenvolvimento Sustentável, 11, 67-72. https://doi.org/10.18378/ rvads.v11i1.3710

Silva, J. A. da, Donato, S. L. R., Donato, P. E. R., Souza, E. dos S., Padilha Júnior, M. C., \& Silva Junior, A. A. (2016a). Extraction/export of nutrients in Opuntia ficus-indica under different spacings and chemical fertilizers. Revista Brasileira de Engenharia Agrícola e Ambiental, 20, 236-242. https://doi.org/10.1590/ 1807-1929/agriambi.v20n3p236-242

Silva, J. A. da, Donato, S. L. R., Donato, P. E. R., Souza, E. dos S., Padilha Júnior, M. C., \& Silva Junior A. A. e. (2016b). Yield and vegetative growth of cactus pear at different spacings and under chemical fertilizations. Revista Brasileira de Engenharia Agrícola e Ambiental, 20, 564-569. https://doi.org/10.1590/1807-1929/ agriambi.v20n6p564-569

Silva, J. A., Bonomo, P., Donato, S. L. R., Pires, A. J. V., Rosa, R. C. C., \& Donato, P. E. R. (2012). Composição mineral em cladódios de palma forrageira sob diferentes espaçamentos e adubações química. Revista Brasileira de Ciências Agrárias, 7, 866-875. https://doi.org/10.5039/agraria.v7isa2134

Silva, J. A., Bonomo, P., Donato, S. L. R., Pires, A. J. V., Silva, F. F., \& Donato, P. E. R. (2013). Composição bromatológica de palma forrageira cultivada em diferentes espaçamentos e adubações químicas. Revista Brasileira de Ciências Agrárias, 8, 342-350. https://doi.org/10.5039/agraria.v8i2a2431

\section{Copyrights}

Copyright for this article is retained by the author(s), with first publication rights granted to the journal.

This is an open-access article distributed under the terms and conditions of the Creative Commons Attribution license (http://creativecommons.org/licenses/by/4.0/). 